\title{
Identification of Somatic Antigens of Adult Fasciola gigantica Isolated from Bali Cattle
}

\author{
Made Sriasih $^{1 *}$ and Ahmad Munjizun ${ }^{2}$ \\ ${ }^{1}$ Faculty of Animal Science University of Mataram, Jl Majapahit 62 Mataram 83125, Lombok, NTB, Indonesia \\ ${ }^{2}$ Graduate Student, Department of Animal Science, North Carolina State University, USA \\ *Corresponding author's Email: madesriasihphd@unram.ac.id; (DORCiD: https://orcid.org/0000-0002-7497-8146
}

\begin{abstract}
In most tropical countries, such as Indonesia, fasciolosis is generally caused by Fasciola gigantica known as tropical liver fluke. However, most fasciolosis serodiagnostic tests have been developed solely for diagnosing fasciolosis caused by Fasciola hepatica (non-tropical liver fluke), and very few have been specifically designed for $F$. gigantica. The aim of this study was to determine the profile of antigenic proteins from the somatic extract of $F$. gigantica isolated from Bali cattle (Bos javanicus). The liver flukes were collected from a slaughtering house in Mataram, Indonesia. The somatic extracts were prepared by homogenizing in buffers containing $0.05 \mathrm{M} \mathrm{NaCl}, 0.02$ M PMSF, and $0.05 \%$ Triton X-100. The characterization of the somatic extract proteins was performed using onedimension gel electrophoresis and followed by Western blotting to determine the profile of its antigenic proteins. There were 14 bands of the somatic extracts with an estimated molecular weight ranging from 8 to $1058 \mathrm{kDa}$ shown on the gel electrophoresis. The results of the Western blot show that there were five prominent protein bands. Three out of five prominent antigenic proteins with molecular weights of 8,27 , and $33 \mathrm{kDa}$ are promising to enrich the existence of antigens that have immunodiagnostic value for fasciolosis. Therefore, further studies are required to examine more deeply the potency of those three antigenic somatic proteins of $F$. gigantica.
\end{abstract}

Keywords: Bali cattle, F. gigantica, Immunodiagnostic, Somatic extract, Western Blot

\section{INTRODUCTION}

Fasciola gigantica and Fasciola hepatica, known as liver fluke, are important parasites of class Trematoda that cause a zoonotic parasitic disease, termed fasciolosis, in humans and animals. In definitive hosts, such as cattle, sheep, goats, and buffaloes, these flukes enter orally and then migrate to the liver through the peritoneal cavity. Fasciolosis have affected 30-80\% of cattle herds in developed countries (Charlier et al., 2014). Moreover, climate change and increased livestock movement have led to a wider range of liver fluke infections in livestock (Howell \& Williams, 2020). In most tropical countries, including Indonesia, the disease caused by $F$. gigantica is detrimental with varying prevalence rates. In Indonesia, the prevalence of fasciolosis in ruminants varies from 40 to 95\% (Estuningsih et al., 2004; Manus and Dalton, 2006; Astiti and Panjaitan, 2012). Worldwide, economic losses caused by Fasciola infection cost at least three billion dollars annually resulting from the loss of weight, decreased fertility, decreased milk and wool production, increased mortality, and high costs for treating infected animals as well as liver damage (Spithill et al., 1999; Abunna et al., 2010; Nyirenda et al., 2019; Arias-Pacheco et al., 2020). This condition is exacerbated by the emergence of resistance to the anthelmintic triclabendazole which is often given as a fasciolosis therapy (Fairweather, 2005).

Fasciolosis incidence in humans has a positive correlation with the incidence of fasciolosis in livestock, and therefore, fasciolosis is a current public concern. This concern is not only because of its high prevalence and economic losses caused by infecting various types of livestock (Schweizer et al., 2005), but also due to its zoonotic nature which can infect humans through ingestion of infective metacercariae (Mas-Coma et al., 2005). World Health Organization (WHO) reported that human fasciolosis has spread in about 70 countries around the world with the number of cases nearly 2.4 million (WHO, 2007). Given its enormous impact on public health, it is necessary to undertake rapid and precise disease control efforts in both livestock and humans.

Disease control can be in the form of prevention and/or treatment in infected hosts. One of the main keys that determines the success of disease control is a correct diagnosis. Traditionally, Fasciola infection in animals is diagnosed by examining the presence of eggs in the feces. However, this method is considered less effective in detecting the parasite at the prepatent stage as eggs will only be produced 12 to 14 weeks after infection (Anderson et al., 1999). In addition, other factors, such as the age of the host, fecal consistency, and the amount of fecal specimen tested, can affect the sensitivity of detection based on egg fecal counting (Rojas et al., 2014).

Serodiagnostic methods, such as enzyme-linked immunosorbent assay (ELISA), offer better sensitivity and specificity than that of traditional methods for the early diagnosis of Fasciola infection (Rojas et al. 2014; Naeemipour 
et al., 2016, Naqvi et al., 2019). Serodiagnostic methods, however, require a number of potent antigens that can recognize the infection during its prepatent period. A variety of Fasciola antigenic components derived from wholeworm (somatic) extract and excretory/secretory (E/S) products, as well as recombinant proteins, have been evaluated and used to develop serodiagnostic tests for ruminants. Amongst those types of antigenic components, the metabolic antigens released in the E/S material of adult parasites remain the main source of potential antigens (Aguayo et al., 2019). Moreover, most of the serodiagnostic tests have been developed solely for diagnosing fasciolosis caused by $F$. hepatica, and very few have been specifically designed for F. gigantica (Kelly et al., 2019).

Considering that the main cause of fasciolosis in tropical countries, including Indonesia, is $F$. gigantica, it is necessary to explore its potential antigenic components for early detection. A recent study carried out by Dar et al. (2019) on various types of antigenic proteins of $F$. gigantica isolated from sheep showed that both somatic and E/S fractions were good sources of antigen. They found that protein bands with molecular weights of 38 and $44 \mathrm{kDa}$ in the somatic fraction, and protein with sizes of 27 and $33 \mathrm{kDa}$ in E/S fraction were very promising to be used for Fasciola detection in sheep. This finding indicates that studies addressing the potential of somatic antigens are also promising to enrich the existence of antigens that have immunodiagnostic value for diagnosis as well as vaccine development. The present study was carried out to determine antigenic components of somatic extract of adult F. gigantica isolated from Bali cattle with promising diagnostic value using Western blotting.

\section{MATERIALS AND METHODS}

\section{Ethical approval}

The process of collecting sera from calves in this study was carried out carefully and in accordance with national guidelines (Animal Health Division, Ministry of Agriculture, Indonesia) for blood collection.

\section{Collection of worms}

Adult worms of $F$. gigantica were collected from the liver of Bali cattle (Bos javanicus) at an abattoir in Majeluk, Mataram, Indonesia March to April 2020. The liver was excised and the adult worms were removed and placed in sterile $0.1 \mathrm{M}$ phosphate-buffered saline (PBS, Sigma-Aldrich) $\mathrm{pH} 7.4$ at $37^{\circ} \mathrm{C}$. Identification of the collected worms as $F$. gigantica was perfomed based on visual gross inspection (brown gray in color, body shape resembles leaves, flat dorsoventral, does not have a clear shoulder shape and longer body length than $F$. hepatica) and morphometric measurements (1.6-3.6 cm x 0.3-0.8 cm) (Oktaviana et al., 2019). The worms were then washed five times with PBS to remove any traces of blood and bile, transported under cold condition immediately to Microbiology and Biotechnology Laboratory of Animal Science Faculty, University of Mataram, Indonesia, and stored at $-80^{\circ} \mathrm{C}$.

\section{Preparation of somatic extracts}

Somatic extracts were prepared according to the method described by Wijffels et al. (1992). Two F. gigantica adult worms were placed and grounded on a mortar, then homogenized using $800 \mu \mathrm{l}$ buffer containing $0.05 \mathrm{M} \mathrm{NaCl}, 0.02 \mathrm{M}$ PMSF, and $0.05 \%$ Triton X-100. The worms were then crushed vigorously using a mortar and pestle to the smallest size possible. The resulting mixture was centrifuged at $10,000 \mathrm{rpm}$ for 30 minutes. The supernatant was then collected and stored at $-20^{\circ} \mathrm{C}$ for further assay.

\section{Sodium dodecyl sulphate polyacrilamid gel electrophoresis}

The F. gigantica somatic proteins were separated according to their molecular weight by Sodium Dodecyl Sulphate-Polyacrilamid Gel Electrophoresis (SDS-PAGE) as described by Laemmli (1970). The SDS-PAGE was performed under reducing conditions with $12 \%$ separating and $6 \%$ stacking gel mixture in Mini Protean II electrophoresis apparatus (Bio-Rad Laboratories, Inc., USA). Prior to loading the gel, the somatic proteins were mixed (1:1) with loading buffer (100 mM Tris-HCL pH 7.0, 4\% SDS, 100\% mercaptoethanol, 0.2 bromophenol blue, and $20 \%$ glycerol). The proteins were then heated in a water bath at $100^{\circ} \mathrm{C}$ for 5 minutes. The gel was run at $100 \mathrm{~V}, 40 \mathrm{~mA}$ for approximately 2 hours, and $5 \mu$ l of Broad-Way Dual pre-stained protein marker (Intron Technology, China) was included on each gel as a size reference. After running completely, the gel was stained using Coomassie brilliant blue dye and let stand for 1 hour. The stained gel was washed in $150 \mathrm{ml}$ acetic acid with gentle shaking for 20 minutes until the protein bands on the gel could be seen.

\section{Western blotting}

The immunoblotting technique was performed according to the method of Towbin et al. (1979). After electrophoresis, the gel was equilibrated in transfer buffer for at least 20 minutes. Nitrocellulose (NC) membrane was pre-incubated in $\mathrm{dH}_{2} \mathrm{O}$ for 2 minutes then was allowed to equilibrate in the transfer buffer for 10 minutes. The transfer of proteins from the gel to the membrane was carried out at a constant voltage of $5 \mathrm{~V}, 0.1 \mathrm{~A}$ for 45 minutes using a Trans- 
Blot $^{\circledR}$ SD Semi-Dry electrophoretic transfer cell (Bio-Rad Laboratories, Inc., USA) as per the manufacturer's instructions. The transfer was confirmed by staining the membrane with $0.2 \%(\mathrm{w} / \mathrm{v})$ Ponceau $\mathrm{S}$ in $30 \%(\mathrm{v} / \mathrm{v})$ trichloroacetic acid for 10 minutes with gentle shaking. The membrane was washed with distilled water until protein bands could be easily visualized.

Following the washing, the membrane was immediately blocked with blocking buffer made from 5\% skim milk in Tris buffer saline-Tween 20 (TBST, pH 7.4 containing $0.1 \%$ Tween 20) at $4^{\circ} \mathrm{C}$ overnight. After washing twice in washing buffer (TBST) the membrane was cut into strips and further incubation of each strip was carried out in individual reservoirs. Each strip was incubated with $10 \mathrm{ml}$ of diluted sera $(1: 100)$ for 1 hour at room temperature or $4^{\circ} \mathrm{C}$ overnight. The sera were taken from cattle confirmed fasciolosis positive or negative (based on the presence of eggs in their fecal samples) so that the antigenicity of the protein on the Western blotting can be determined. Each strip was then washed for five 5-10-minute cycles with washing buffer. After washing, diluted anti-bovine IgG-HRP (Sigma- Aldrich) 1:8000 was applied and incubated for 1 hour at room temperature, and followed by washing step as previously described. Immunodetection for each strip was carried out by adding $1.5 \mathrm{ml}$ of 3,3',5,5'-tetramethylbenzidine (TMB, SigmaAldrich) substrate as recommended by the manufacturer. The strips were then dried for further analysis.

\section{Molecular weight determination}

The molecular weight (MW) of the somatic protein bands both in SDS-PAGE and Western blot was determined by comparing the migration rate of the protein against the known standard migration rate of the standard protein markers. The relative mobility (Rf value) of both the standard marker bands and each of the dominant bands from the sample was calculated $(\mathrm{Rf}=$ migration distance of band $\div$ migration distance of dye front). The protein $\mathrm{MW}$ in each band was calculated by substituting the Rf value to the regression equation obtained from two standard marker bands flanking the intended band $(\mathrm{y}=\mathrm{ax}+\mathrm{b})$. Finally, the MW was determined by calculating the anti-log of $\mathrm{y}$ value $(10 \mathrm{y})$.

\section{RESULTS AND DISCUSSION}

\section{Somatic protein profiles of $\boldsymbol{F}$. gigantica isolated from Bali cattle}

Protein profile characterization is the first step that must be taken to determine protein candidates that can be used as a basis for vaccine production, medicinal development, or development of diagnoses in overcoming various diseases, including fasciolosis, that has spread sporadically both in Indonesia and throughout the world. There have been many methods used to separate protein molecules in a sample (Allam et al., 2002), including SDS-PAGE. The SDS-PAGE is a technique that is still widely used to estimate the number of polypeptides and the complexity of the protein in samples or purified samples (Garfin, 2003). The working principle of SDS-PAGE is the separation of protein molecules that occurs due to differences in the speed of each protein in which smaller proteins migrate faster than the larger proteins.

The results of the characterization of the somatic protein components of the F. gigantica isolated from Bali cattle are presented in Figure 1. Based on the SDS-PAGE results as presented in Figure 1, the somatic protein profiles in lanes 1 to 3 show that after the separation of proteins based on their MW, the protein bands look very thick so that it is difficult to distinguish between one band and the other one. The thickness of the protein bands illustrates the amount of protein with similar MW in each band. The best dilution that shows clear protein separation in Figure 1 is in lane 4 with 1:2 dilution. The SDS-PAGE results in lane 5 show the presence of 14 dominant bands (band number 1 to 14 ) of $F$. gigantica somatic protein extract.

Table 1 shows the MW of the dominant proteins resulting from SDS-PAGE gel electrophoresis. There are 14 protein bands with estimated MW of 8, 16, 17, 21, 27, 30, 33, 37, 43, 52, 58, 73, 89 and $105 \mathrm{kDa}$. El-Rahimy et al. (2012) compared the antigen components between $F$. gigantica and $F$. hepatica and showed that there were differences in the molecular weight of 13 types of protein as evident from the SDS-PAGE results between $F$. gigantica and $F$. hepatica. The size of the proteins, however, only ranged from 9.1 to $35.7 \mathrm{kDa}$ (El-Rahimy et al., 2012). The most dominant protein in the study performed by El-Rahimy et al. (2012) were proteins with MW of 29.3, 26, and 19 kDa. The SDS-PAGE results from the somatic extract in this study indicated the presence of protein bands with molecular weight up to $89 \mathrm{kDa}$ with the most dominant proteins being proteins with the MW of 8, 16, 17, 27, to $37 \mathrm{kDa}$. These differences may be related to the influence of age of infection which is correlated to age and species of flukes $(F$. gigantica and F. hepatica) (Estuningsih and Widjajanti, 1999), the effect of host species (Mas-Coma et al. 2005), and the influence of different geographic locations of research objects (Sobhon et al., 1996; Meshgi et al., 2008). Estuningsih and Widjajanti (1999) compared protein profiles of $F$. gigantica of five different ages (juvenile, 3 weeks, 6 weeks, 9 weeks, and adult). They found that a number of protein bands found in adult flukes samples were not present in the other-age sample groups. Differences in protein profiles have also been associated with host species. De Vera et al. (2009) compared protein profile of Fasciola sp. between two different host, cattle (Bos taurus) and water buffalo (Bubalus bubalis). They found that although the worms between the two host species shared some common protein bands, a number of bands were found to be bubaline specific for both $F$. hepatica and $F$. gigantica. Species-related differences in protein bands of the fluke samples was also reported by Lee et al. (1992), who infected cattle, llama, rats, and mice with $F$. hepatica. They found that the variation was higher in E/S samples than the whole body prtoein, suggesting that the 
differences may be associated with different metabolism in responsse to different host species (Lee et al., 1992; De Vera et al., 2009). In regards with different geographic locations, there were some differences in nucleotide sequences of internal transcribed spacers (ITS-1 and ITS-2) of Fasciola sp. ribosomal DNA from various countries and this may relate to the different origins of the trematodes (Itagaki et al., 2005; Alasaad et al., 2007; Ali et al., 2008; Farjallah et al., 2009).

Another important factor to consider is the calculation of molecular weights for each protein band in the gel, which is relative to the molecular weight of the protein marker. It is notable that the logs of the marker do not show a completely linear curve (Figure 2). Therefore, the calculation of the protein band molecular weights would be more accurate by generating the linear regression from each two adjacent marker bands. The intended protein bands that fall between these known bands, hence, can be obtained using the respective formula. Meanwhile, the molecular weights that are obtained from the linear regression of the whole marker bands would result in the less accurate calculation since the $\log$ MW of all protein bands are forced to be linear. The calculation method and the accuracy in determining the band migration distance in the gel would affect the results, in which similar proteins could possibly be written in slightly different molecular weights. This can be solved by further study through the sequencing process.

\section{Antigenic protein profile of $\boldsymbol{F}$. gigantica somatic extract based on Western blot analysis}

Western blotting is a technique that is widely used to detect protein expression in a cell or tissue extract (Kurien $\&$ Scofield, 2006). The principle of the method which consists of several stages is to determine the presence or absence, size, and modification, or degradation of a target protein and as far as possible can determine the quality of the protein itself (Taylor et al., 2013). This technique measures the protein level in a biological sample through antibody binding to the specific protein desired. Western blot can detect a specific protein in materials containing a number of proteins and can provide information about that specific protein (Dechend et al., 2006; Sakudo et al. al., 2006).

Nine Bali cattle serum samples consisting of six fasciolosis-positive samples and three fasciolosis-negative samples (based on the results of examining the presence or absence of eggs in the feces) were used in the current study to determine the reactions between the somatic antigens and specific antibodies in the serum samples. The somatic antigenic protein profile of the F. gigantica using the Western blot method is presented in Figure 3 . The results of the Western blot showed that there were 5 prominent proteins. The molecular weight of each protein band from the Western blot results is presented in Table 2.

Data from Figure 3 show that proteins with MW of 70 and $47 \mathrm{kDa}$ appeared only on the NC membrane incubated with negative samples (lane 9). Proteins with MW of 33 and $27 \mathrm{kDa}$ were present in nearly all membranes incubated with fasciolosis-positive serum samples but were also recognized by two negative samples (lanes 8 and 9). This phenomenon may indicate that these proteins are potential for further investigation using a larger population of positive and negative samples. The protein with an MW of $8 \mathrm{kDa}$ only appeared in three of the six positive samples.

The immunoblotting results in the current study indicated that the antigenic protein was represented by a protein band with an MW of $8 \mathrm{kDa}$. The $8 \mathrm{kDa}$ protein bands were recognized by $50 \%$ of bovine serum infected with fasciolosis and did not appear on the NC membrane that was probed with negative samples. The absence of that antigenic protein on the other three positive samples was probably due to the different responses of each individual to an antigen (Mas-Coma et al., 2005).

The results of the present study are very interesting since an antigenic protein with a size of $8 \mathrm{kDa}$ is rarely recognized as a specific antigen in various experiments. In line with the findings of the current study, Kim et al. (2003) stated that the use of $8 \mathrm{kDa}$ protein from crude extract fractionation of $F$. hepatica in detecting fasciolosis gave good results without any cross-reaction with other trematode infections. Of the five positive serum samples used in their study (Kim et al., 2003), four of them were recognized as an antigen with a molecular weight of $8 \mathrm{kDa}$ and none appeared in the negative samples. The results of the study carried out in our research are similar to that of De-Almeida et al. (2007) on the evaluation of the immune response of patients infected with fasciolosis. The findings indicated that the antigen with a molecular weight of $8 \mathrm{kDa}$ was the dominant molecule recognized by the patient's antibody.

The proteins with molecular weights of 33 and $27 \mathrm{kDa}$ appeared in all positive samples (100\%) but were also recognized by two negative samples (Figure 3), indicating that these proteins were still potential as antigenic proteins in our study. This is because the determination of the fasciolosis-positive and -negative samples used was based on the presence or absence of worm eggs in the feces, which was less sensitive than the serological method. Worm eggs would not be found in the feces of fasciolosis-infected livestock if the worms present in the liver are not yet sexually mature although specific antibodies are already formed. Some researchers claimed that proteins with MW of $33 \mathrm{kDa}$ and $27 \mathrm{kDa}$ are specific antigens. Gonenc et al. (2003) suggested that a protein with a molecular weight of $33 \mathrm{kDa}$ was the most potential antigen for diagnosis. Rivera-Marrero et al. (1988) also reported that the protein band weighing 25-30 kDa of the ES antigen was a specific protein for acute and chronic fasciolosis in rabbits, cattle, and sheep. Sampaio-Silva et al. (1996) stated that $F$. hepatica with molecular weights of 25 and $27 \mathrm{kDa}$ were the most sensitive antigens to serum infected with fasciolosis. Mohamed et al. (2004) again emphasized that the antigens that were immunoreactive against the serum of patients infected with fasciolosis were 25-29 kDa and $12 \mathrm{kDa}$, which were purified from crude extracts of F. hepatica. Farghaly et al. (2009) reported that the diagnosis using the Western blot method using Fasciola E/S antigens showed that in all fasciolosis infected patients, an antigen with MW of $27 \mathrm{kDa}$ gave the highest specificity, sensitivity, and accuracy to detect Fasciola antibodies. 
The use of somatic extracts as an antigen source for serological diagnosis has been developed by previous researchers. Farghaly et al. (2009) affirmed that the use of somatic extracts of $F$. hepatica in the Falcon assay screening test (FAST)-ELISA method showed sensitivity, specificity, positive and negative predictive values of $92.5 \%, 86.7 \%$, $89 \%, 82.2 \%$, and $94.5 \%$, respectively. Another fasciolosis study showed that the use of a somatic antigen to determine the IgG-ELISA response demonstrated a sensitivity of $100 \%$ with a specificity of $96.4 \%$, with positive and negative predictive values of $97.8 \%$ and $100 \%$, respectively (Rokni et al. 2003). The results of these studies indicate that the use of somatic extracts as an antigen source for the diagnosis of fasciolosis is very feasible to develop.

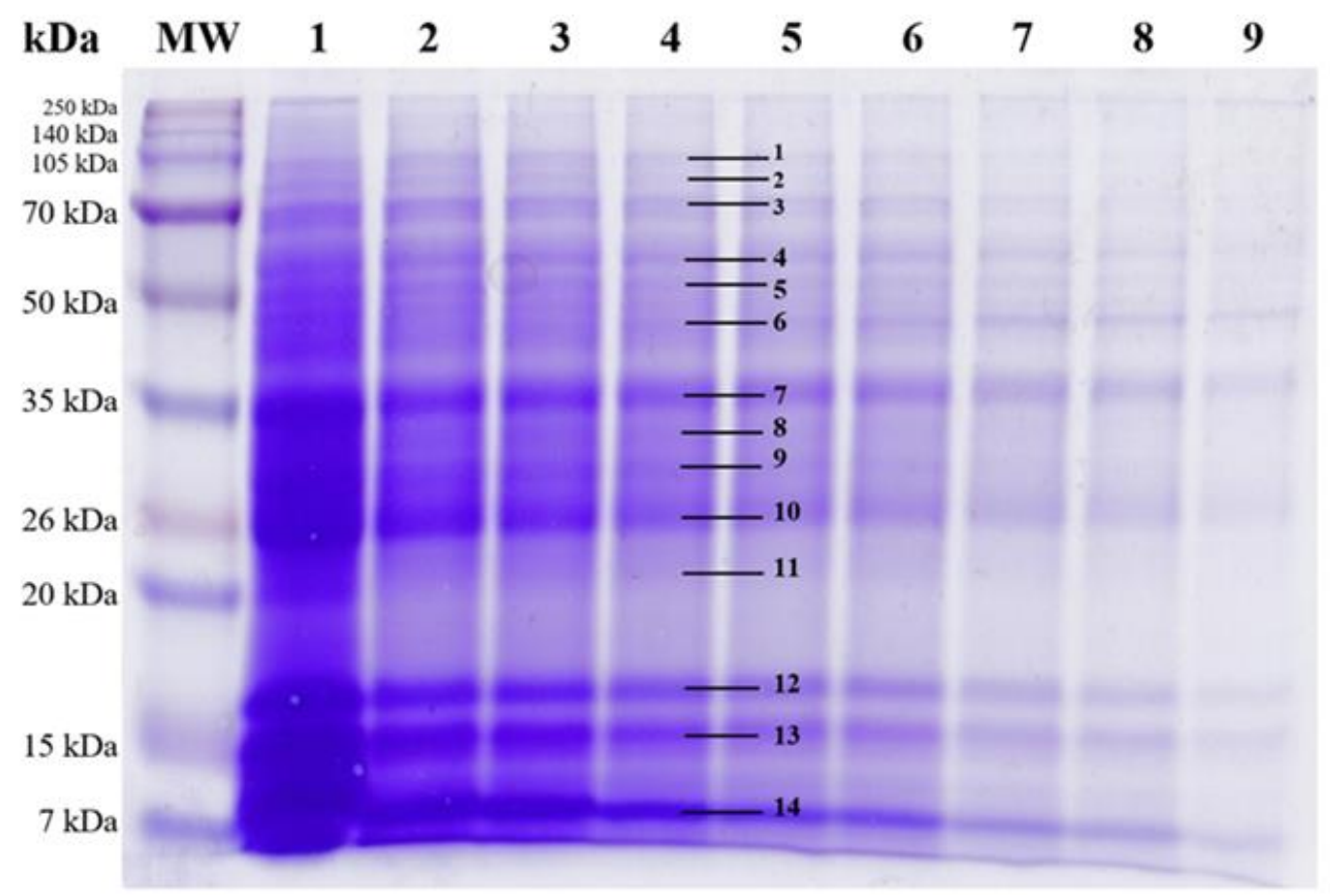

Figure 1. Characterization of the $F$. gigantica somatic proteins using sodium dodecyl sulphate polyacrilamid gel electrophoresis. Lane molecular weight $(\mathrm{MW})$ : Protein standard marker. Lane 1-2: Somatic protein extract without dilution. Lane 3: Somatic protein extract diluted $1 \mathrm{x}$ in phosphate-buffered saline. Lane 4: Somatic protein extract diluted 2x in phosphate-buffered saline. Lane 5: Somatic protein extract diluted 3x in phosphate-buffered saline. Lane 6: Somatic protein extract diluted $5 \mathrm{x}$ in phosphate-buffered saline. Lane 7: Somatic protein extract diluted 10x in phosphate-buffered saline. Lane 8: Somatic protein extract diluted 20x in PBS. Lane 9: Somatic protein extract diluted 40x in phosphate-buffered saline.

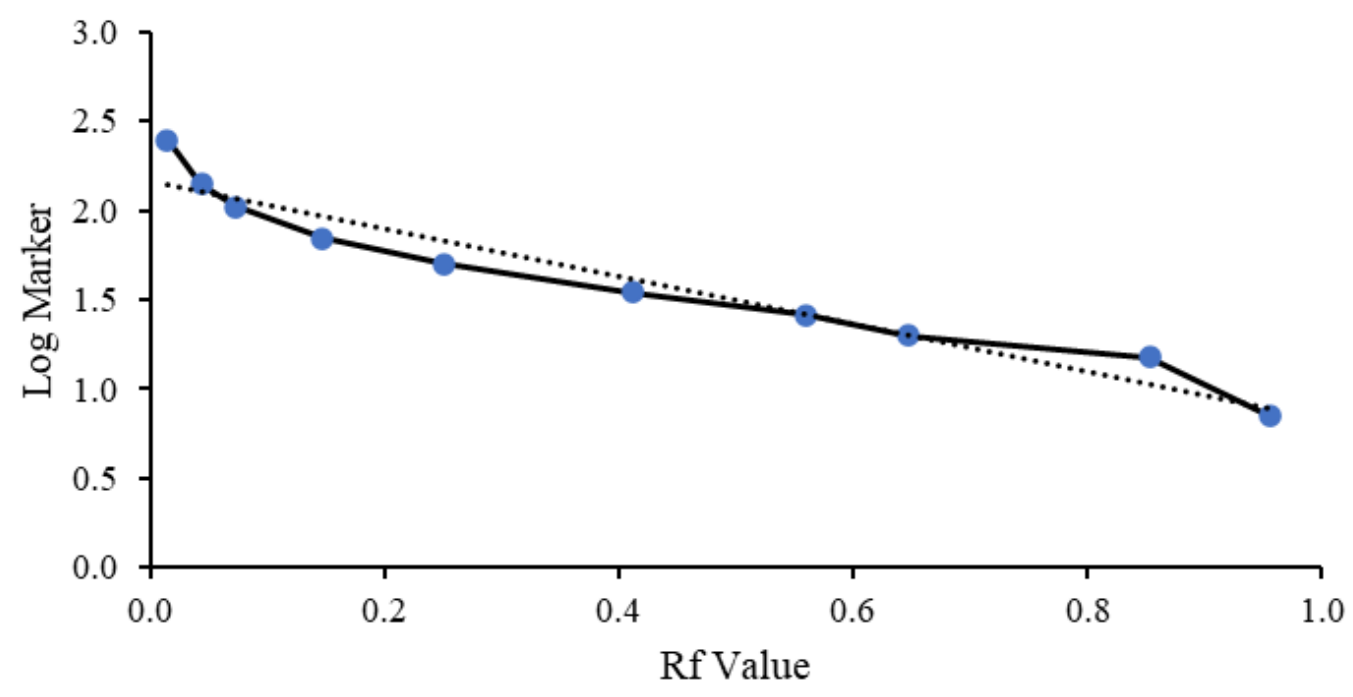

Figure 2. Standard protein molecular weight curves in sodium dodecyl sulphate polyacrilamid gel electrophoresis. The $\log$ molecular weight of the intended protein bands should fall within the black gridlines. 


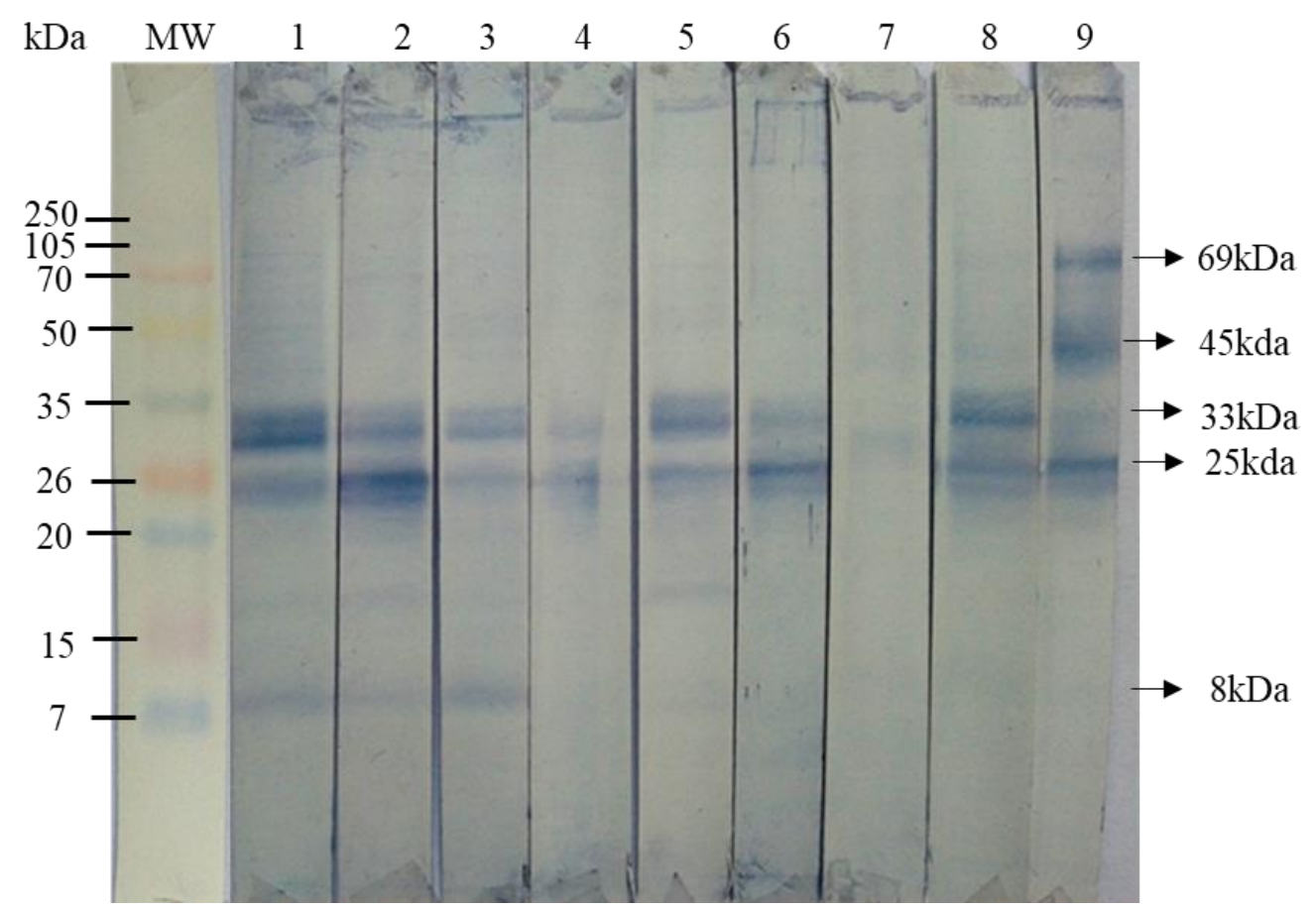

Figure 3. Western blot analysis of somatic extract of adult $F$. gigantica isolated from Bali cattle. Lane MW: Protein standard marker. Lane 1-6: Probed with fasciolosis positive sera. Lane 7-9: Probed with fasciolosis negative sera.

Table 1. Calculation of the molecular weight of sodium dodecyl sulphate polyacrilamid gel electrophoresis results based on the regression value.

\begin{tabular}{lcccccc}
\hline Band number & $\begin{array}{c}\text { Distance } \\
(\mathbf{m m})\end{array}$ & $\mathbf{R f}(\mathbf{x})$ & Slope (a) & $\begin{array}{c}\text { Intercept } \\
(\mathbf{b})\end{array}$ & $\mathbf{Y}(\mathbf{a x + b )}$ & $\begin{array}{c}\text { MW }(\mathbf{1 0}) \\
(\mathbf{k D a})\end{array}$ \\
\hline 1 & 5 & 0.074 & -2.3948 & 2.1973 & 2.02 & 105 \\
2 & 7 & 0.103 & -2.3948 & 2.1973 & 1.95 & 89 \\
3 & 9 & 0.132 & -1.4195 & 2.0539 & 1.87 & 73 \\
4 & 14 & 0.206 & -1.4195 & 2.0539 & 1.76 & 58 \\
5 & 16 & 0.235 & -1.4195 & 2.0539 & 1.72 & 52 \\
6 & 20 & 0.294 & -1.4195 & 2.0539 & 1.64 & 43 \\
7 & 26 & 0.382 & -0.9576 & 1.9384 & 1.57 & 37 \\
8 & 30 & 0.441 & -0.9576 & 1.9384 & 1.52 & 33 \\
9 & 33 & 0.485 & -0.8778 & 1.9055 & 1.48 & 30 \\
10 & 37 & 0.544 & -0.8778 & 1.9055 & 1.43 & 27 \\
12 & 43 & 0.632 & -1.2914 & 2.1366 & 1.32 & 21 \\
13 & 52 & 0.765 & -0.6068 & 1.6937 & 1.23 & 17 \\
14 & 56 & 0.824 & -0.6068 & 1.6937 & 1.19 & 16 \\
\hline
\end{tabular}

Note: mm: Millimeter, Rf: Relative mobility, MW: Molecular weight.

Table 2. The molecular weight of each protein band from the Western blot.

\begin{tabular}{lcccccc}
\hline No. & $\begin{array}{c}\text { Distance } \\
(\mathbf{m m})\end{array}$ & $\mathbf{R f}(\mathbf{x})$ & Slope (a) & Intercept (b) & Y ax+b & $\begin{array}{c}\text { MW (10 } \\
(\mathbf{k D a})\end{array}$ \\
\hline 1 & 17 & 0.262 & -1.8997 & 2.3419 & 1.8450554 & 70 \\
2 & 23 & 0.354 & -1.6781 & 2.2669 & 1.6731108 & 47 \\
3 & 29 & 0.446 & -1.3985 & 2.1465 & 1.5225538 & 33 \\
4 & 33 & 0.508 & -1.4813 & 2.1898 & 1.4377554 & 27 \\
5 & 52 & 0.8 & -3.5858 & 3.7689 & 0.90026 & 8 \\
\hline
\end{tabular}

Note: $\mathrm{mm}=$ millimeter; $\mathrm{Rf}=$ relative mobility; $\mathrm{MW}=$ molecular weight 


\section{CONCLUSION}

Identification of protein from the somatic extracts of $F$. gigantica isolated from Bali cattle on one-dimension gel electrophoresis showed that there are 14 protein bands with MW ranging from 105 to $8 \mathrm{kDa}$. The Western blot results determined that three out of five prominent antigenic proteins with $\mathrm{MW}$ of $8 \mathrm{kDa}, 27 \mathrm{kDa}$, and $33 \mathrm{kDa}$ are promising to enrich the existence of antigens that have immunodiagnostic value for fasciolosis. Therefore, further studies are required to examine more deeply the potency of those three antigenic somatic proteins of $F$. gigantica.

\section{DECLARATIONS}

\section{Authors' contribution}

Made Sriasih and Ahmad Munjizun are equally contributed to designing, analyzing, and writing the manuscript. All authors read and approved the final manuscript.

\section{Competing interests}

All authors have declared no conflict of interests.

\section{Acknowledgments}

The authors are grateful to the University of Mataram Indonesia, and the Indonesian Ministry of Education and Culture for providing financial assistance to carry out this study. The authors also wish to thank all staff and technicians who were very helpful.

\section{REFERENCES}

Abunna F, Asfaw L, Megersa B, and Regassa A (2010). Bovine fasciolosis: coprological, abattoir survey and its economic impact due to liver condemnation at Soddo municipal abattoir, Southern Ethiopia. Tropical Animal Health and Production, 42 (2): $289-292$. DOI: https://doi.org/10.1007/s11250-009-9419-3

Aguayo V, Valdés FBN, Rodríguez-Valentín M, Ruiz-Jiménez C, Ramos-Benítez MJ, Méndez LB, Espino AM (2019). Fasciola hepatica GST

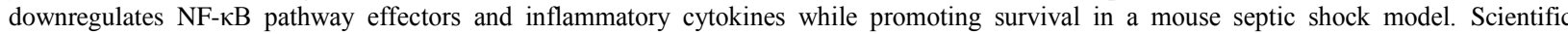
Reports, 9, 2275. https://doi.org/10.1038/s41598-018-37652-xSci Rep 9:2275

Alasaad S, Huang CQ, Li QY, Granados JE, García-Romero C, Pérez JM and Zhu XQ (2007). Characterization of Fasciola samples from different host species and geographical localities in Spain by sequences of internal transcribed spacers of rDNA. Parasitology Research, 101(5):1245-1250. doi:10.1007/s00436-007-0628-2

Ali H, Ai L, Song HQ, Ali S, Lin RQ, Seyni B, Issa G and Zhu XQ (2008). Genetic characterisation of Fasciola samples from different host species and geographical localities revealed the existence of F. hepatica and F. gigantica in Niger. Parasitology Research, 102(5):1021-1024. doi:10.1007/s00436-007-0870-7

Allam AF, El-Agamy, ESI and Helmy MH (2002). Molecular and immunological characterization of Fasciola species. British Journal of Biomedical Science, 59:191-195. DOI: 10.1080/09674845.2002.11783658

Anderson N, Luong TT, Vo NG, Bui KL, Smooker PM, and Spithill TW. 1999. The sensitivity and specificity of two methods for detecting Fasciola infection in cattle. Veterinary Parasitology, 83: 15-24. DOI: 10.1016/s0304-4017(99)00026-6

Arias-Pacheco C, Lucas JR, Rodríguez A, Córdoba D and Lux-Hoppe EG (2020). Economic impact of the liver condemnation of cattle infected with Fasciola hepatica in the Peruvian Andes. Tropical Animal Health and Production. Published online 22 January 2020. https://doi.org/10.1007/s11250-020-02211-y

Astiti LGS, and Panjaitan T (2012). Mapping of fasciolosis on Bali cattle in Lombok. International Conference on Livestock Production and Veterinary Technology, 416-421. Indonesian Center for Animal Research and Development, Bogor, Indonesia. http://medpub.litbang.pertanian.go.id/index.php/proceedings

Charlier J, Vercruysse J, Morgan E, Van Dijk J and Williams DJL (2014). Recent advances in the diagnosis, impact on production and prediction of Fasciola hepatica in cattle. Parasitology, 141:326-335. DOI: 10.1017/S0031182013001662

Dar JS, Tak I, Ganai BA and Shahardar RA (2019). Studies on various types of antigenic proteins of Fasciola spp. as a basis for the immunodiagnosis and vaccine development: A review. International Journal of Biotechnology and Molecular Biology Research. Vol. 7(4) pp. 36-43, October 2016 DOI: $10.5897 /$ IJBMBR2015.0241

De-Almeida MA, Ferreira MB, Planchart S, Terashima A, Maco V, Marcos L., Gotuzzo E., Snchez E, Nquira C, Scorza JV and Incani RN (2007). Preliminary antigenic characterisation of an adult worm vomit preparation of Fasciola hepatica by infected human sera. Revista do Instituto de Medicina Tropical de São Paulo, 49(1): 31-35. DOI: 10.1590/S0036-46652007000100006

De Vera ME, Sato K, Oyong G and Claveria FG (2009). Comparison of protein profile of co-existing Fasciola hepatica and Fasciola gigantica parasite in Bos taurus (cattle) and Bubalus bubalis (Philippine water buffalo). The Journal of Protozoology Research, 19(1): 1-9. https://doi.org/10.32268/jprotozoolres.19.1_1

Dechend R, Homuth V, Wallukat G, Muller DN, Krause M, Dudenhausen J, Haller H and Luft FC (2006). Agonistic antibodies directed at the angiotensin II, AT1 receptor in preeclampsia. Journal of the Society for Gynecologic Investigation, 13(2):79-86. DOI: 10.1016/j.jsgi.2005.11.006

El-Rahimy HH, Mahgoub AM, El-Gebaly NS, Mousa WM and Antably AS (2012). Molecular, biochemical and morphometric characterization of Fasciola species potentially causing zoonotic disease in Egypt. Parasitology Research, 111: 1103-1111. DOI: 10.1007/s00436-012-2938-2

Estuningsih SE and Widjajanti S (1999). Characterisation of protein antigen from Fasciola gigantica of different age. Jurnal Ilmu Ternak dan Veteriner 4 (1): 60-64. http://dx.doi.org/10.14334/jitv.v4i1.138

Estuningsih SE, Widjajanti S, Adiwinata G, and Piedrahita D (2004). Detection of coproantigen by sandwich ELISA in sheep experimentally infected with Fasciola gigantica. Tropical Biomedicine, 21(2):51-56. PMID: 16493398. https://pubmed.ncbi.nlm.nih.gov/16493398/

Fairweather I (2005). Triclabendazole: new skills to unravel an old (ish) enigma. Journal of Helminthology, 79: 227-234. doi: 10.1079/joh2005298

Farghaly AM, Nada SMM, Emam WA, Mattar MA Mohamed SMA, Sharaf EM and El- Gamal RA (2009). Role of Fast-ELISA and Western Blot in diagnosis of human Fascioliasis using crude adult worm and excretory/secretory Fasciola antigens. Parasitologists United Journal (PUJ). 1 (2) 55 - 65. https://vlibrary.emro.who.int/imemr/role-of-fast-elisa-and-western-blot-in-diagnosis-of-human-fascioliasis-using-crude-adult-worm-andexcretory-secretory-fasciola-antigens-2/ 
Farjallah S, Sanna D, Amor N, Ben Mehel B, Piras MC, Merella P, Casu M, Curini-Galletti M, Said K and Garippa, G. (2009). Genetic characterization of Fasciola hepatica from Tunisia and Algeria based on mitochondrial and nuclear DNA sequences. Parasitology Research, 105(6):1617-1621. doi:10.1007/s00436-009-1601-z

Garfin DE (2003). Gel Electrophoresis of Proteins. In: Davey J and Lord M (eds) Essential cell biology. Oxford University Press, Oxford, pp $197-268$.

Gonenc B, Sarimehmetoglu HO, Kara M, and Kircali F (2003). Comparison of crude and ES antigens for the diagnosis of F. hepatica in sheep by Western Blotting. Turkish Journal of Veterinary and Animal Science, 28:943-949. https://www.researchgate.net/publication/275520873 Comparison of crude and excretorysecretory antigens for diagnosis of Fasciola hepati ca_in_sheep_by_Western_blotting

Howell AK and Williams DJL (2020). The epidemiology and control of liver flukes in cattle and sheep. Veterinary Clinic: Food Animal Practice, 36:109-123. https://doi.org/10.1016/j.cvfa.2019.12.002

Itagaki T, Kikawa M, Sakaguchi K, Shimo J, Terasaki K, Shibahara T and Fukuda K (2005). Genetic characterization of parthenogenic Fasciola sp. in Japan on the basis of the sequences of ribosomal and mitochondrial DNA. Parasitology, 131(5):679-685. doi:10.1017/s0031182005008292

Kelly RF, Mazeri S, Hartley C, Hamman SM, Ngwa VN, Nkongho EF, Tanya V, Sander M, Ndip L, Morgan KL, Muwonge A, Handel I, de Bronsvoort BMC and Williams DJL (2019). Assessing the performance of a Fasciola gigantica serum antibody ELISA to estimate prevalence in cattle in Cameroon. BMC Veterinary Research (2019) 15:8. https://doi.org/10.1186/s12917-018-1762-Z

Kim K, Yang HJ and Chung YB (2003). Usefulness of $8 \mathrm{kDa}$ protein of Fasciola hepatica in diagnosis of Fascioliasis. The Korean Journal of Parasitology. 41 (2): 121-123. DOI: 10.3347/kjp.2003.41.2.121

Kurien BT and Scofield RH (2006). Western Blotting. Method, 38(4):283-93. DOI: 10.1016/j.ymeth.2005.11.007

Laemmli UK (1970). Cleavage of structural proteins during the assembly of the head of bacteriophage, T4. Nature, 227 : 680-685. https://doi.org/10.1038/227680a0

Lee CG, Zimmerman GL and Bishop JK (1992). Host influence on the banding profiles of whole body protein and excretory-secretory product of Fasciola hepatica (Trematoda) by isoelectric focusing. Veterinary Parasitology, 41(1-2): 57-68. DOI: 10.1016/0304-4017(92)90008-w

Manus, MDP and Dalton JP (2006). Vaccines against the zoonotic trematodes Schistosom japonicum, Fasciola hepatica and Fasciola gigantica. Parasitology, 133(S2): 543 - 562. DOI: 10.1017/S0031182006001806

Mas-Coma S, Valero MA and Bargues MD (2005). Fasciolosis and other plant-borne Trematoda zoonoses. International Journal of Parasitology, 35: 1255- 1278. DOI: 10.1016/j.ijpara.2005.07.010

Meshgi B, Eslami A and Hemmatzadeh F (2008). Determination of somatic and excretory-secretory antigens of Fasciola hepatica and Fasciola gigantica using SDS-PAGE. Iranian Journal of Veterinary Research, 9(1):77-80. doi: 10.22099/ijvr.2008.526

Mohamed MM, Al-Sherbiny MM, Sharaf AA and Elmamlouk TH (2004). Immunological identification of Fasciola hepatica antigens containing major human T-cell and B-cell epitopes. Journal of the Egyptian Society of Parasitology, 34(3):751-766. https://pubmed.ncbi.nlm.nih.gov/15587304/

Naeemipour M, Hashemitabar GR, Dastjerdi K, Mojaver MJ and Mohammadi HR (2016). Comparison of fecal egg counts and ELISA for the diagnosis of Dicrocoelium dendriticum infection. Polish. Journal Veterinary Science, 19:573-580. https://doi.org/10.1515/pjvs2016-0072.

Naqvi MA-UN, Jamilb T, Naqvia SZ, Memona MA, Aimulajianga K, Aleema MT, Ehsana M, Xua L, Songa X, Lia X and Yana R (2019). Immunodiagnostic potential of recombinant tropomyosin during prepatent Haemonchus contortus infection in goat. Research in Veterinary Science, 128: 197-204. DOI: 10.1016/j.rvsc.2019.11.013

Nyirenda SS, Sakala M, Moonde L, Kayesa E, Fandamu P, Banda F and Sinkala Y (2019). Prevalence of bovine fascioliasis and economic impact associated with liver condemnation in abattoirs in Mongu district of Zambia. BMC Veterinary Research, 15:33. https://doi.org/10.1186/s12917019-1777-0

Oktaviana A, Suratma A and Wandia N (2019). Morphometry of liver fluke (Fasciola gigantica) infecting Balinese cattle. Journal of Veterinary and Animal Sciences, 2(1): 10-17. DOI:https://doi.org/10.24843/JVAS.2019.v02.i01.

Rivera-Marrero CA, Santiago N and Hillyer GV (1988). Evaluation of immunodiagnostic antigens in the ES products of $F$. hepatica. The Journal of Parasitology, 74(4):646-652. PMID: 3294367. https://pubmed.ncbi.nlm.nih.gov/3294367/

Rojas CAA, Jex AR, Gasser RB and Scheerlinck JP (2014). Techniques for the diagnosis of Fasciola infections in animals: room for improvement. Advances in Parasitology, 85, 65-107. DOI: 10.1016/B978-0-12-800182-0.00002-7

Rokni MB, Massoud J, and Hanilo A (2003). Comparison of adult somatic and cysteine proteinase antigens of Fasciola gigantica in Enzyme linked Immunosorbent Assay for serodiagnosis of human Fasciolosis. Acta Tropica, 88(1): 69-75. DOI: 10.1016/s0001-706x(03)00175-X

Sakudo A, Suganuma Y, Kobayashi T, Onodera T and Ikuta K (2006). Near-Infrared Spectroscopy: promising diagnostic tool for viral infections. Biochemical and Biophysical Research Communication, 341(2):279-84. DOI: 10.1016/j.bbrc.2005.12.153

Sampaio-Silva ML, Da Costa JM, Da Costa AM, Pires MA, Lopes SA and Castro AM (1996). Antigenic components of ES products of adult F. hepatica recognized in human infections. The American Journal of Tropical Medicine and Hygiene, 54(2):146-148. DOI: 10.4269/ajtmh.1996.54.146

Schweizer G, Braun U, Deplazes, P and Torgerson PR (2005). Estimating the financial losses due to bovine Fasciolosis in Switzerland. The Veterinary Record, 157: 188-193. DOI: 10.1136/vr.157.7.188

Sobhon P, Anantavara S, Dangprasert T, Meepol A, Wanichanon C, Viyanant V, Upatham S, Kusamrang T, Chompoochan T, Thammasart S and Prasittirat P (1996). Fasciola gigantica: identification of adult antigens, their tissue sources and possible origins. ScienceAsia, 22 : 143 - 162. doi: 10.2306/scienceasia1513-1874.1996.22.143

Spithill TW, Smooker PM, and Copeman DB (1999). Fasciola gigantica: epidemiology, control, immunology and moleculer biology. In: Dalton, J.P. (Ed), Fasciolosis. CAB International, Wallingford, pp.465-525.

Taylor SC, Berkelman T, Yadav G and Hammond M (2013). A defined methodology for reliable quantification of Western Blot data. Molecular Biotechnology, 55(3):217-226. DOI: 10.1007/s12033-013-9672-6

Towbin H, Staehelin T and Gordon J (1979). Electrophoretic transfer for proteins from polyacrylamide gels to nitrocellulose sheets: procedure and some application. Proceedings of the National Academy of Sciences of the United States of America, 76(9):4350-4354. doi: 10.1073/pnas.76.9.4350

Wijffels GL, Sexton JL, Salvatore L, Petitt JM, Humphris DC, Panacio M and Spithill TW (1992). Primary sequence heterogeneity and tissue expression of Glutathione S-Transferase of Fasciola hepatica. Experimental Parasitology, 74 (1): 87-99. DOI: 10.1016/0014-4894(92)90142-w

World Health Organization (2007). Report of the WHO Informal Meeting on Use of Triclabendazole in Fascioliasis Control. WHO Headquarters, Geneva, Switzerland. https://www.who.int/neglected_diseases/preventive_chemotherapy/WHO_CDS_NTD_ 